\title{
The dawla and the umma
}

lilmw i adwa (sa sbt eiinadstate).

[Mankind was but one nation, then it fell into variance.]

Quran 10:19

As muezzins recite calls to prayer from the minarets of mosques across the region, Muslims are reminded of the obligations of their faith. Fajr marks a universal start to the day before the complexities of contemporary life create countless trajectories of possibility, as life becomes shaped by the contingency of the political. Beyond this universal call, muezzins are divided by subjectivity, space, time and the complexity of everyday life. Unlike other religions, Islam is seen to be well equipped to provide guidance to its followers on circumventing the seductive trappings of this life, offering explicitly political instructions on how best to live life through adherence to the Quran and Sunna - seen to be Divine Law - yet the very interpretation of such texts by infallible human agency brings in subjectivity, couched in contingency, which leads to division, difference and ultimately, the erosion of God's sovereignty.

This chapter focuses on competing claims of authority found within religion and their political repercussions. To do this, it uses the concept of the state of exception to identify a zone of indistinction that is inherent within a number of political projects deriving legitimacy from religion. Much like the discussion of turath in the previous chapter, it is concerned with how the collapse of religion into politics and politics into religion creates a zone of indistinction, along with contesting the relationship between ordnung and ortung that transcends the traditional understanding of political organisation. In this zone, regimes are able to circumvent domestic - and regional - contestation but are simultaneously contested through recourse to such systems of belief, with serious repercussions for political life across the Middle East.

In a book entitled Islamic Exceptionalism: How the Struggle Over Islam Is Reshaping The World, Shadi Hamid argues that because of its inherently political nature, Islam is fundamentally different to other religions, albeit with different visions of political 
meaning shaping contemporary political life. ${ }^{1}$ This identification of the political nature of Islam is not new, with a range of scholars suggesting that the religion was established alongside a political community led by the Prophet, which was inherently concerned with the ordering of people, not space. Moreover, such scholars also argue that the Quran offers guidance on all facets of life, which makes it political. Of course, these views are contested. Nazih Ayubi argues that this approach is Orientalist and that the Quran offers no explicit guidance on political life and community, albeit using a narrow definition of politics. ${ }^{2}$ This view supports the position of Sheikh Ali Abd Al Raziq, an Egyptian jurist whose framing of Islam as apolitical helped support the development of sovereign entities after the First World War, while also permitting Muslim heads of state to have relations with non-Muslim states. ${ }^{3}$

Yet this too is not without problems. One approach is to reject Abd Al Raziq's thesis that political authority is not part of Islam, suggesting that Sharia can be applied to the contemporary world. ${ }^{4}$ A second approach stems from a discussion of Islamic conceptions of society initially identified by Khaldun but developed by other Muslim thinkers who stressed the importance of adding the seemingly coeval conception of the state to society as a means of safeguarding the latter. ${ }^{5}$

Fundamental to discussion about the relationship between religion and politics is the source of sovereignty. For Muslims, God is the source of sovereignty and as the Quran proclaims, 'It is God unto whom belongeth the sovereignty of the heavens and earth'. ${ }^{6}$ But while sovereignty is found in God, questions arise as to who should rule on earth after the death of the Prophet. Andrew F. March suggests that different interpretations of authority offer a range of ways to resolve such questions. First, political authority is seen as a form of contract between rulers and ruled, when a council of representatives selected a leader to guide the community in accordance with his message. A second view is that God's will is embodied in the corpus of the divine law itself and so divine sovereignty is derived from the extent to which God's law is applied, albeit opening up a raft of new questions in the process. ${ }^{7}$

\section{Religion and politics}

On 1 April 1979, less than three months after the abdication of the Shah of Shahs, Iranians voted to establish an Islamic Republic on the basis of principles espoused by Grand Ayatollah Ruhollah Khomeini who was later installed as Supreme Leader of the new state. Khomeini had returned to Iran on 1 February where he was greeted by an estimated crowd of five million who had grown angry at the Shah's regime. Over the course of the protests, political opposition to the Shah coalesced around Khomeini's vision, some more willing than others amid allegations that the revolution was hijacked by Khomenei, but in the months that followed, Islam played a prominent role in regulating life across the new republic. ${ }^{8}$

The new republic placed Shia values at the centre of its approach to politics, both domestic and foreign and, as such, dramatically altered the nature of Middle Eastern 
politics. Values of resistance and counter-hegemony became integral to understanding Tehran's foreign policy, extrapolating from the Karbala Narrative in Shi'a history. ${ }^{9}$ Revolutionary fervour dramatically altered the regional order, fusing geopolitical concerns with sectarian schisms seen in the establishment of Hizballah ${ }^{10}$ and provision of support for other Shi'a groups across the region. Following such support, in the years that followed, the blame for domestic unrest in states with sectarian tensions was firmly placed on Iran.

Later the same year, a group of Saudi tribesmen led by Juhayman Al Utaybi entered the Grand Mosque in Mecca and seized control of it by force. The group held the belief that modernisation strategies deployed by the Al Saud - coupled with their 'un-Islamic' behaviour - were contrary to Islam. Al Utaybi garnered support from disaffected groups across the kingdom and gained credibility through his family lineage; his ancestors had been part of the ikhwan rebellion of the 1920s, which rose up against Ibn Saud's state-building project for its departure from the rightful path of Islam. Events in Mecca shook the kingdom, revealing the fragility of the Al Saud's relationship with their Islamic backers and stressing the complexity of the dual path of political rule and adherence to Wahhabist doctrine.

Amid the rapid transformations of the previous decades across the region, such unrest was hardly surprising. Transformation from empire to colonial rule fashioned a range of different experiences and interpretations of Islam, demonstrating the contingency of relationship between state, regime and society. Within anti-colonial and nationalist movements, religion took on an important role beyond faith as a means through which collective identities could be mobilised and alternative visions of political organisation could be established. Islam also initially served as a source of culture and tradition for the nascent Arab nationalist movement, along with providing the means through which the movement could spread, but while it initially lost ground to projects espousing Arab unity, the importance of Islam as a means of ordering politics and space remained.

There is little doubt that Islam has had a dramatic impact on the political arena, existing in numerous forms: from the puritanical Wahhabism in Saudi Arabia to the quietist Ibadism in Oman, via competing visions of the role of clerics in Shia thought. This plurality of interpretations has implications for the ordering of life for individual believers, communities and states even before they are placed in the context of political life and parabolic regional currents. Yet much like nomos, Islamic unity proved to be an illusion. Instead, competing interpretations of faith and the ordering of life in accordance with Islamic traditions quickly emerged, in some cases, operating in tension with state projects. One of the most devastating points of tension concerns sectarian difference.

Few terms possess such vitriolic connotations as sectarianism which, in recent years, has become imbued with all manner of issues pertaining to identity politics and violence. Although there is a complex history of relations between the different sects of Islam, there is nothing inherently violent about this difference. In recent times it has become imbued with negative connotations, amid the perception of deviating from the norm, while also being extended to include political and ethnic minorities. ${ }^{11}$ As a consequence, as Fanar Haddad acknowledges, the concept of sectarianism has become 
almost meaningless. Deeply politicised and emotionally charged, the concept has become a 'catch-all' term, an elastic concept applied to a range of issues that can often be understood as everything from the perfectly legitimate expressions of sect-centric behaviour to inter-sect violence. ${ }^{12}$ Consideration of the concept reveals tensions about the construction of identity and debate between primordialists and constructivists. ${ }^{13}$ Putting this debate aside, we can identify three distinct periods where inter-sect violence escalated to play a prominent role in regional politics in 1979, 2003 and 2011; unsurprisingly, regional politics also shape the relationship between sects and broader political communities. These periods correspond with crises in regional politics: the Iranian Revolution, the Iraq War and the Arab Uprisings.

The mobilisation and manipulation of sect-based identities for political reasons has been a common feature of political life. After the fall of the Ottoman Empire, sectbased identities were mobilised for political purposes, both domestic and regional, as regimes attempt to exert control and influence and, ultimately seek to ensure their survival. Speaking to constituents is one means through which this can be achieved, while also strengthening claims to unity through fear of the other. Efforts to regulate the territorially bounded polis often involve recourse to religion, which transcends territoriality. As such, given recourse to a shared normative environment we can see how internal actions can have regional repercussions.

Contemporary debates on the role of religion across the Middle East are characterised by tension over the extent to which religion shapes politics or politics shapes religion. Yet the role of religion is far more complex that being reduced to two opposing positions. Indeed, a religious community should not be viewed as a monolithic, homogenous bloc; instead, in addition to doctrinal differences, we must also consider movements on the left and right, economical disparities, the conservative, the peaceful and violent, allowing for context-specific contingencies to shape analysis. Religion is also a site of tension between tradition and modernity, best seen in the anachronistic demands of fundamentalist movements to return to the golden ages of their faith. At its heart is a desire to ensure that religion retains a 'authoritative' position within contemporary life; although what this authoritative position looks like is open to interpretation.

The emergence of an 'Islamist revival' during the 1970s sought to challenge the status quo across the region, arguing that political trajectories had failed and that only Islam could correct this failure. Across the region, Islam occupied a seemingly contradictory place within states, acting as a legitimising tool yet also posing a serious threat to regime stability and sovereign power. ${ }^{14}$ As a result, regimes faced a delicate balancing act to ensure that Islamic legitimacy was maintained while also restricting the capacity for groups to charge regimes with impropriety or to use the mosque as a means through which to challenge political elites and also regulate life; religion itself became a zone of indistinction and a site of possibility for political empowerment, repression and everything in-between. A range of methods were used to regulate and control the role of Islam within state structures including constitutional reform and the marginalisation of particular individuals and groups. Ultimately, however, religious groups were largely unable to seize power, leading Olivier Roy's famous claim about 
'the failure of political Islam ${ }^{15}$ and, later, a move towards post-Islamism amid debate about the role of religion in society, politics and the public sphere.

The importance of contingent factors that shape the place of religion in society means that we cannot understand such groups and their place within societies - or across the region more broadly - without putting them into political, social and legal contexts. In support of this, Asef Bayat stresses the importance of social agents and the context in which they operate in order to understand group behaviour and the characteristics of faith. ${ }^{16}$ As Shahab Ahmed suggests, current 'analytical conceptualisations' of Islam fall short of 'identifying the coherent dynamic of internal contradiction which lies at the crux of any successful conceptualisation of Islam as a human and historical phenomenon. ${ }^{17}$ From this position we can see the emergence of a number of 'Islams' contingent upon context. This leads to inherent diversity, difference and disagreement, a point stressed by Ahmed who argues that 'Muslims have long been well aware that they are not all the same ... that their identity as components of universal Islam includes diverse experiences, agreement, disagreement ... that they mostly agree to disagree and be different.'18

The logical conclusion of such an argument is the idea that each Muslim is simultaneously an instance of 'local imam' and a member of the universal community of Muslims. ${ }^{19}$ This distance in positions is also populated by membership of different communities, from family, tribe, sect or state. Running Ahmed's argument to its conclusion, with competition over symbolic forms and manifestations of Islam, 'there can be only one true Islam, and that is usually the believer's own. ${ }^{20}$ Such a position leads to serious tensions between competing visions of unity, from local community to broader claims to the umma, along with disparate views of the ordering of life. Moreover, it also opens up debate about the relationship of religion and territory with discussions about dar al Islam, the land of Islam and dar al harb, literally the 'land of war' but better understood as any contested territory not under Islamic rule. ${ }^{21}$ Parallels also emerge with the concept of the nomos, which draws people together amid shared belief in a particular vision but implodes after a fleeting instance of unity. Managing such difference is fundamentally a political task, albeit couched in theological dissonance.

From this, faith serves simultaneously as a source of legitimacy and an existential threat to political stability and the future of the territorially grounded sovereign state. Religion is a means through which opposition can emerge through the existence of competing sovereignties, yet it retains an integral position within mechanisms of control. One of the mechanisms through which regimes create bare life is through the manipulation of religious structures and the cultivation of sectarian difference. To understand such processes we must explore the means through which regimes have 'played' with both religion and the law, co-opting both formal and normative structures within the framework of political organisation. ${ }^{22}$

Although Islam is seen to be all encompassing with God the source of all laws, we cannot isolate it from context and socio-economic facts, for it is through engagement with such a reality that region exists and evolves. As James Piscatori suggests, 'even a religious code such as Islam must be accepted as variable and evolving with changing circumstances. ${ }^{23}$ From this, it is easily apparent that when placed within political, 
social, economic and historical context, religion has a prominent role in ordering and regulating life. Joseph Schacht, one of the foremost scholars on Islam notes how Islam is biopolitical in nature: '[T]he central feature that makes Islamic religious law what it is, that guarantees its unity in all its diversity, is the assessing of all human acts and relationship, including those which we call legal, from the point of view of the concepts. ${ }^{24}$ At the heart of the biopolitical project is the regulation of life, which serves as a means of exerting control across populations and defining the spatial borders of political organisation in the process.

As Dale Eikelman and James Piscatori suggest, politics takes on an Islamic dimension through 'the invocation of ideas and symbols, which Muslims in different contexts identify as "Islamic", in support of ... organized claims and counterclaims'. Given that a plurality of ideas and symbols can be used amid a range of different interpretations of such symbols, it appears obvious that there can then be myriad definitions of political Islam. ${ }^{25}$ It is generally accepted that most Muslims hold the law to be 'divine and sacred, revealed through the Quran and the Sunna. Yet in application and interpretation, law is not monolithic or without critical reflection as it is interpreted by 'infallible' actors who are products of the contingency of time and space. Comprised of both formal and normative aspects - where rules and rituals merge - the establishment of the rule of law and its meaning within Islam is contingent upon the relationship between religion, law and the nature of political organisation. Thus, local histories and cultural narratives shape such contingency, feeding into the construction of what a person is refrained from doing and with it, spatial boundaries. ${ }^{26}$

Put another way by Joseph Schacht:

The central feature that makes Islamic religious law what it is, that guarantees its unity in all its diversity, is the assessing of all human acts and relationship, including those which we call legal, from the point of view of the concepts 'obligatory/recommended/indifferent/reprehensible/forbidden.'.

Yet with the societal, political and technological developments since the establishment of Sharia, the regulation of conduct is 'unsettled' ${ }^{28}$ leading to different interpretations shaped by local contingency. This, in itself, is a source of consternation for many such as Mawdudi, who hold that God's law must govern over the infallible contingency of human-made laws. ${ }^{29}$

Debate over ideas and their application in political contexts has long been a source of contention. Efforts to circumvent such issues and to appease disparate groups of people have required developing reserves of legitimacy. Demonstrating the importance of retaining Islamic legitimacy, a number of states sought to demonstrate legitimacy and compliance with Sharia by establishing Sharia guarantee clauses, designed to offer guidance on 'what Islamic states were permitted to do. ${ }^{30}$ Such clauses have to be applied constitutionally, requiring a particular set of clauses to ensure compliance and ratification of theological requirements in both public and private realms. Of course, the development of these clauses led to doubt concerning elements of historical Islamic legal thought while also resulting in factionalism within dar al Islam. ${ }^{31}$ 
Amid efforts to create unity among such difference, there is often recourse to an 'ideal' time of Islam. Although the 'golden age' of Islam is often heralded as the most ideal period, leading many Salafists to desire the somewhat anachronistic return to such a time, this was a highly idealised period that bore little resemblance to contemporary narratives of the time. ${ }^{32}$ With this in mind, it is important to remember that religion exists within contingent factors in order to provide a more holistic picture of events. Moreover, we must also recognise the tension between public and private, which becomes particularly important during the apparent rise of post-Islamism and the move away from formal structures of Islamic teaching.

Such issues are not limited to Islam but emerge when considering the relationship between other faiths and politics. In Israel, the complex relationship between state and synagogue has been equally contested. The interaction of faith with different interpretations of Zionist ideology - themselves shaped by different socio-economic, cultural and historical experiences - has resulted in a melange of different groups operating both inside and outside the recognised borders of the state of Israel. Moreover, in the case of groups such as the Hilltop Youth and Gush Emunim (along with a number of others) there is a rejection of the legitimacy of the state and its borders, with the groups' members seeking to alter the geographical parameters of the state.

\section{Religion, authority and interpretive dissonance}

Facing challenges to their sovereignty, Middle Eastern rulers have long sought to circumvent contestation through the construction of exclusionary projects that fuse faith, tradition and culture. ${ }^{33}$ Yet recourse to religion or culture does not necessarily preclude others from subscribing to particular communities and, perhaps, such constructions create scope for further contestation across state boundaries. The establishment of mandate-era territorially grounded forms of political organisation created colonial forms of statehood, clashing with the prominence of Islam in political structures. ${ }^{34}$ Although not theological concepts, dar al Islam and dar al harb are classical legal doctrines treated in the Sharia that help to regulate interactions between Muslims and non-Muslims that are not necessarily separated territorially. The establishment of territorially defined forms of political organisation in the mandate period were thus directly at odds with a religion that recognised 'no boundaries for its kingdom'. ${ }^{35}$

In addition to this clash of territorial principles, the evolution of political organisation during the state-building process required the transition of social dynamics from largely rural, tribal and Bedouin communities to more sedentarised and urban communities. Regulating life in these new communities was of paramount importance and constitutions provided scope through which to achieve this goal, yet most of the newly urban population were not familiar with the workings of constitutional documents and, amid the uncertainty of their new life, found certainty in religion. Most states across the region positioned Islam centrally, with the Sharia 
serving as a source of laws within constitutions, yet religion also plays an important role in regulating behaviour through the establishment of a normative code that believers subscribe to.

To understand how religion is used within contemporary politics we must begin by engaging with a dichotomy that shaped interactions between Islam and politics in the formative stages of state-building processes. Islam as a religion occupies a space within both theological and political realms as the Prophet Mohammad served both as a head of faith and also as the leader of a political community and this tension remains. The Madinah Constitution that governed political life under Mohammad is widely believed to be the first written constitution. Theories of politics and the state within Islam and Islamic law are shaped by the interaction of these two difference concepts but it is debate about the ultimate source of sovereignty that are of paramount importance. Within Islam, God is sovereign, the ultimate source of law and authority. The Quran supports such a position: 'Allah is the One who has sent the Messenger with guidance and the religion of truth to prevail over all religions. ${ }^{\text {'36 }}$

It also provides guidance as to how to live: 'verily those decrees guide you to my straight path, so follow the way and do not follow other paths. ${ }^{37}$ Given its holistic nature, Islam is a public faith, seeking to regulate political activity to maintain wellbeing and as such, it provides guidance on all facets of life. It follows that the Sharia is the basic constitution for Muslims and written political constitutions across the region pay heed to this, acknowledging the Quran and Sharia as providing guidance in how to live. From such a position it is easy to see how Islam can be seen as a political religion, although issues of interpretation arise amid efforts to regulate the complexities of modern life.

The history of Islam is one replete with difference, from the Khawarij to the Shi'a manifesting not only in theological and political schisms, but also within sects. ${ }^{38}$ The spread of Islam across the Middle East means that different sects and interpretations within sects have created allegiances within and across states and challenged the spatial regulation of life in the process.

In engaging in debate about sovereignty, one must consider its roots, limitations and the right of rebellion, representation and relationship between Sharia, democracy and policy enactments. ${ }^{39}$ How one answers such questions is contingent upon context, both within and between states, where history and interpretation are important in shaping the relationship between Islam and political structures and ultimately, political life. With its focus on the regulation of life, Islam has long possessed a political dimension. As we have seen, however, with the plurality of views and interpretations, political decisions require legitimisation - often by the ulema - who justify rule by stressing that their authority is a consequence of either the sovereignty of Divine Law, or the contract between ruler and ruled. ${ }^{40}$ The relationship between ruling elites and prominent clerics is then of paramount importance when considering stability within a territory, where human order is to conform to 'the Divine norm. ${ }^{41}$

Here lies a fundamental tension within debate about religious sovereignty. While some argue that Divine Law is the source of sovereignty, others suggest that the very interpretation of Divine Law brings subjectivity and human infallibility into the 
theological realm, diluting God's message. Such a conclusion results in numerous challenges to the sovereign order, particularly among efforts to derive legitimacy and authority from theological sources.

During the fragmentation of empire, political figures sought to codify aspects of Islamic law within constitutions as a means of ensuring regime survival in the face of burgeoning nationalist movements. Around this time, Egyptian scholars at Al Azhar sought to repudiate claims made by Alī 'Abd Al Rāziq that the Prophet Mohammad was a religious messenger, without political doctrine. ${ }^{42}$ In response, Muhammad Rashīd Riḍā argued that justice, equality and accountability are found within Islam and are regulated by following the correct path:

As far as civil and social governance is concerned, Islam laid down its foundation and principles, and prescribed for the umma that it employ judgment and discretion in this area, because it changes along with time and place and it advances along with civilization and knowledge. Among its basic principles is that authority over and command of the umma belongs to it itself [sultat alumma laha] and that its affairs are a matter of consultation within it. ${ }^{43}$

Rida's views were influential on the ideas of Hassan Al Banna, the founder of the Muslim Brotherhood, for whom Islam served as a political response to colonial projects, bringing the political into the theological and the theological into the political. The colonial legacy, Al Banna suggests, can be found in the very establishment of nations and nationalities across the Arab world. ${ }^{44}$ Yet all too aware of the need to tailor comments to particular audiences, prima facie consideration of Al Banna's speeches suggest that they are rife with contradiction, particularly over the idea of a nation. In a letter to Egypt's King Faruq in 1948, Al Banna wrote that 'Islam is guaranteed to supply the renascent nation with its needs. ${ }^{45}$ For Al Banna, one of the main objectives of the Brotherhood was to 'establish Allah's sovereignty over the world. To guide all of humanity to the precepts of Islam and its teachings (without which mankind cannot attain happiness)'. ${ }^{46}$

The formation of the Muslim Brotherhood as a political movement marks the establishment of an Islamist group, an organised collective believing that Islam should play a prominent role in the organisation of public life. The creation of the group was a conscious act of political agency, simultaneously a response to modernity and a product of it. ${ }^{47}$ Yet the group was not homogenous, reflecting the importance of contingency and interpretation. As the Brotherhood's ideological canon developed, it also began to fragment.

In contrast to Al Banna, Sayyid Qutb argued that the world is steeped in jähiliyya, stemming from 'rebellion against the sovereignty of God on earth'. Supporting this, Qutb argued that rebellion emerged from

attempts to transfer to man one of the greatest attributes of God, namely sovereignty, by making some men lords over others ... in the more subtle form of claiming that the right to create values, to legislate rules of collective behavior, and to choose a way of life rests with men, without regard to what God has prescribed. ${ }^{48}$ 
Intellectual tensions between Qutb and Al Banna reflect fissures within Islamist movements themselves, concerning activity and spatial arena, but shaped by different contexts that give old ideas new meanings. Since the 1970s, a more nuanced form of engagement with debates about their role in politics has emerged, which sees some Islamist groups taking a more active role in civil society, in addition to those more radical groups for whom violence is viewed as the means to achieve their goals. This view reflects the contingency of modernity and local factors in shaping the relationship between religion, law and politics. A secondary dimension emerges, concerning the relationship between Islamist groups across state borders and the extent to which groups should operate at a transnational or national level. ${ }^{49}$

How one understands Islam and the contingent factors that determine its position in - and beyond - the state defines the relationship between religious and political realms. In accordance with the emergence of the modern state, religious belief and practice is subordinate to state structures. Yet for most Muslims, the law is divine and sacred and for many, legal doctrine - as revealed in the Quran and Sunna - must be immune from critical discourse. God is seen to be the ultimate sovereign, the final arbiter of power and the source of all laws. Yet questions still remain over territorial control. Following this, for Michelle Burgis, authority is derived from God's authority from application of Sharia to $u m m a$ - and not through the regulation of territory. ${ }^{50}$

\section{Religious revivalism: engagement, opposition and failure?}

Today the Jurists of Islam are proofs (of God) to the people, proofs of the Imam. Total obedience is owed to them, since they are specially appointed by the Prophet to be his successors and to rule. The Jurists' authority in government affairs is equal to that of the Prophet and of the Imams, since they all share in common the burden of executive power to apply the divine law. ${ }^{51}$

As we saw in the previous chapter, the prevalence of authoritarianism stems from regime efforts to ensure the survival of their rule. Supporting this, Mounia BennaniChraibi suggests that the main reason for authoritarian persistence was 'to remain in power and protect their personal interests ... [and as a result they often have] to defend themselves against their own people. ${ }^{52}$ Within this context, access to political space became restricted. One way in which groups could gain access was through religion, as a consequence of state reliance upon religious views to maintain legitimacy and authority. As we shall see, the notion of political community is a source of much contestation within Islamic thought, with the repercussions of such debates having serious implications for state sovereignty and security. This type of debate raises a number of questions about the spatial ordering of society and the means through which society is regulated. The resolution of debates over the role of Islam within political community can provide the means through which ruling elites can strengthen their claims over political leadership, both ideologically and materially.

When state structures begin to fragment, people are forced to find alternative sources of support to meet their basic needs. ${ }^{53}$ From this vacuum, opportunities 
emerged for groups such as the Muslim Brotherhood, Hizballah and Badr Brigades to gain prominence through the provision of social goods and services. A number of these groups desired a political role, yet beyond Iran, they were largely unsuccessful, prompting a move towards 'post-Islamism', which saw the relocation of religion from public to private realms. Before we reach this point, however, let us briefly trace the role of religion within political life.

After the fall of the Ottoman Empire and establishment of the mandate system, questions about the role of religion within the fabric of newly established states were central to the construction of political organisation. The struggle over the place of religion in the public realm is perhaps best seen across twentieth-century Turkey, as the struggle to locate religion was integral in shaping the political nature of the state. In Iraq, mandate forces sought to restrict the influence of the clerics of the south by allying with the Sunni minority and establishing a monarchical system that restricted the political influence of the Shi'a clerics. In Mandatory Palestine, Jews continued to make aliyah, establishing settlements and kibbutzim as a mechanism of transforming land, coordinated by the Jewish Agency and, while religion was important, Marxistinspired material factors played a prominent role in activity at this time.

From the 1940 s to the 1960 s regimes and religious groups typically worked in unison, in battle against secular, leftist and pan-Arab ideologies that threatened the political status quo. ${ }^{54}$ Nowhere was this more apparent than in Jordan, where the influx of Palestinian refugees after the nakba created fertile ground for populist ideologies to spread. In this context, the Muslim Brotherhood established a political wing, the Islamic Action Front. Of course, relations between the Brotherhood and the regime would fluctuate, based upon the interaction of domestic and regional dynamics. While religion operates as a means of legitimising political rule, it also serves as a doubleedged sword, providing scope for groups to challenge the status quo within this zone of indistinction. ${ }^{55}$ A number of groups have challenged regimes in this zone, accusing them of not upholding religious values, doing so from both inside and outside political systems; both legally and illegally.

With the discovery of oil, the role of religion within society became more prominent as regimes sought to ensure their legitimacy amid widespread economic and social development. With the rapid and in many cases existential transformation of societies that took people from rural to urban settings and challenged their traditions, faith provided a sense of certainty. While some rulers such as Faisal Al Saud were able - and willing - to demonstrate their piety, others such as Anwar Sadat, the 'Believer President', sought to position themselves in a way to harness the power of religion..$^{56}$ This revivalism has resulted in even greater diversity within the concept of political Islam, between and within sects, over the use of violence and, once again, as to the final vision.

The discovery of oil also shaped the trajectory of a state's foreign policy, as the proliferation of Islamist narratives and visions began to be used as a mechanism to challenge the pan-Arab vision. The financing of a range of different actors in several contexts was fuelled by the exponentially increasing Saudi petro-dollars during the 1970s. This financial clout allowed Wahhabist thought to attain a 'preeminent position of strength' across global manifestations and expressions of Islam, achieved in no small part through the establishment of the Islamic University of Medina. ${ }^{57}$ 
The 'crisis of Arab nationalism' in the aftermath of the 1967 war provided the kingdom with the opportunity to challenge Egypt as the dominant regional actor through the mobilisation of pan-Islamist narratives. Poor socio-economic conditions left the region ripe for Islamic narratives to challenge the bulbous Arab nationalist regimes, and these Islamic narratives spread across increasingly disaffected urban populations, along with those marginalised from elite politics. The flows of workers, ideas and capital that began in the 1970s only served to facilitate the dawa (call to Islam) through the spread of Wahhabist ideas, ${ }^{58}$ supported by seemingly inexhaustible financial resources, much like in Qatar that also follows Wahhabi thought. While Saudi funding for groups across the world began in earnest in the 1970s, Qatari support became more prominent in the years after the Arab Uprisings as the state embarked on a more proactive foreign policy. Yet Wahhabism would not be accepted by all, given their fundamentalist approach to faith and association with the Al Saud dynasty, ${ }^{59}$ whose behaviour was viewed by some as incompatible with strict Islamic doctrine. ${ }^{60}$

Islamist parties often referred to religion as a means of eroding the political credentials of ruling elites, seeking to demonstrate the impropriety of rulers, ultimately arguing that they were unfit to rule. All too aware of the challenges posed by mosques and their capacity for mobilisation, regime observation and restriction of Friday prayers was hardly surprising. In spite of this, those leading the prayers were able to frame sermons within the word of God, leaving criticism implicit and avoiding direct incitement. Yet by not performing within the accepted limits of Islam, one is then trapped by the mobilisation of such narratives, wherein the double-edged sword served simultaneously as a means to legitimise and criticise.

The prominence of Islam within state building is perhaps best seen in the establishment of Saudi Arabia and the ongoing efforts to ensure the legitimacy of the Al Saud. With less than favorable tribal and nationalist credentials, the alliance with Wahhabist ulema was essential in the establishment of the state. Due to a centuriesold alliance between the $\mathrm{Al}$ Saud and Wahhabi clerics, religion has served a dual role in the kingdom, providing the means for the Al Saud to gain legitimacy and also to develop a national identity. Contingent factors of time, place and economic context stress the importance of a strong communal identity, amid disparate historical, tribal and religious experiences, which mean that identity has been built around the power of the Al Saud family and its Islamic values. Nationalist narratives evoke collective memory of history, territory and societal love; the Saudi nationalism revolves around faith and loyalty to the Al Saud, the Protectors of the Two Holy Places of Islam. The need to maintain this social contract in spite of evolving socio-economic conditions has thus proved central in the very survival of the Saudi state.

Islam occupies a central role within the Saudi legal system, with the Sharia as the source of its laws - underpinning the Basic Law of 1992 - while concepts such as qanun (law) and musharr'i (legislator) were peripheral in political discourse to prevent the emergence of challenges to Sharia. ${ }^{61}$ The prominence of Islam in legal and political structures is not without issues, however, as it raises questions as to the source of sovereign power. As we have seen, sovereignty is exercised through the declaration of an emergency and the sovereign decision, yet a zone of indistinction emerges here when considering clauses within the Basic Law. 
Article 61 states that, 'The King declares a state of emergency, general mobilisation and war, and the law defines the rules for this', while Article 62 offers more guidance on this. From our earlier discussion about the sovereign decision this is hardly surprising. However, consideration of earlier articles and principles appears to challenge this. Article 1, for example, states that: 'The Kingdom of Saudi Arabia is a sovereign Arab Islamic state with Islam as its religion; God's Book and the Sunnah of His Prophet, God's prayers and peace be upon him, are its constitution, Arabic is its language and Riyadh is its capital.' Building on this, Article 7 states that, 'Government in Saudi Arabi derives power from the Holy Quran and the Prophet's tradition', while Article 11 begins, 'Saudi society will be based on the principle of adherence to God's command'. It is quickly apparent that a fundamental tension emerges as to the source of sovereignty; while the monarch takes the decision, the roots of sovereignty appear to lie elsewhere. ${ }^{62}$

The alliance between Wahhabism and Al Saud is mutually beneficial, ensuring the survival - and ultimately predominance - of both clerics and statesmen. The coercive apparatus of the state protects religion while the Sharia legitimises the state, preventing it from descent into tyranny. ${ }^{63}$ It is, of course, a relationship not without tension, as seen with the ikhwan rebellion against Ibn Saud's forces in the 1920s out of concern at modernisation processes going against Islamic values and the seizure of the Grand Mosque in $1979 .{ }^{64}$ In response to criticism about Islamic practice, the state supported ulema issued fatwas legitimising regime actions when necessary ${ }^{65}$ and in the years after the seizure of the Grand Mosque, the importance of the ulema for political survival was increasingly apparent. ${ }^{66}$

In addition to the fatwa justifying action in the Grand Mosque, a similar fatwa was issued to restrict Shi'a political activity:

The Rafidah of the Hasa [al-Ahsa'] be obliged to surrender to true Islam and should abandon all their defective religious rites. We asked the Imam, Ibn Saud, to order his viceroy in al- Hasa, Ibn Jiluwi, to summon the Shi' is to Shaikh ibn Bishr, before whom they should undertake to follow the religion of God and his Prophet and to cease the invocation of the saintly members of Ahl al-Bayt, and to abandon other innovations in their public assemblies, and to conform to the rule of prayer five times daily in the mosque. Prayer callers (muaddhin) are to be sent. The people are also to study the three principles of the Wahhabi tenets; their houses of worship are to be destroyed and those that object to this will be exiled.

With regard to the Shi'is of Qatif, we have advised the Imam to send missionaries and preachers to certain districts and villagers, which have come under the control of the true Muslims and in which Shariah laws should be put in effect. ${ }^{67}$

The fatwa reveals the Wahhabi suspicion and rejection of Shi'a beliefs and, given the prominence of the ulema within the fabric of the Saudi state, the kingdom's Shia population were subjected to widespread discrimination and marginalisation. ${ }^{68}$ 
Much like in Saudi Arabia, consecutive regimes in Egypt sought to facilitate the bureaucratic co-option of the ulema of Al Azhar. Having witnessed the influence of the clerics of the ulema across the previous decades, ${ }^{69}$ Nasser sought to solidify his rule by bringing the clerics 'to heel', in what was described as the 'capitulation of the ulema to the state. ${ }^{70}$ Yet the clerics quickly ascertained their importance and sought to improve their position within bureaucratic structures as they recognised their value in countering challenges posed by the Muslim Brotherhood and their Saudi neighbours. The reforms also had the unintended by-product of political empowerment as expansion created new forms of expertise, negatively seen by some as bricolage - the fragmented intellectual constructions of Islamist protest ${ }^{71}$ - but later serving as a means of political empowerment. ${ }^{72}$

The struggle to regulate society was far greater than the struggle to regulate the ulema, as the Brotherhood occupied a prominent role within civil society, providing much needed social goods and services. The Brotherhood itself had spent a great deal of time reflecting on the desired place of the organisation within Egyptian society, as a public, political actor, noted by its founder Hassan Al Banna, who recounted that 'No one but God knows how many nights we spent reviewing the state of the nation ... analysing the sickness, and thinking of the possible remedies. So disturbed were we, that we reached the point of tears.'

Under Anwar Sadat, the 'Believer President', the political constraints placed on Al Azhar were loosened as he sought to use religion as a mechanism of legitimacy and to achieve political goals just as his predecessor had done. While Nasser had used the clerics of Al Azhar to legitimise arrests of the Muslim Brothers, Sadat provided greater space for Islamic expression as he sought to limit the power of the Nasserist cabal although it was here that prominent members of the ulema demanded greater influence. The rise of jamaa Takfir wa Hijra, a group that capitalised on tensions between regime and ulema, led to the clerics taking a stronger line against more militant forms of Islamist action and moving towards the centre of the political arena. Following the assassination of Sadat, his successor Hosni Mubarak sought to crush the threat posed by radical Islam while also co-opting the ulema and increasing the regime's Islamic legitimacy by giving them administrative responsibility and control over a number of areas. $^{73}$

In Jordan, Islamist movements provided the means to challenge the burgeoning Arabist, leftist and Palestinian movements. These opportunities secured the Hashemite monarchy in the face of a number of threats, while also building upon one pillar of their domestic legitimacy, namely descent from the Prophet. In the first fifty years of the state, an implicit alliance between the Hashemites and the Muslim Brotherhood increased monarchical claims to legitimacy by using the Brotherhood's networks to speak to populations through informal channels. At this time, the ikhwan in Jordan was dominated by Palestinians and thus working with the Muslim Brotherhood provided another means for the Hashemite regime to secure its rule. Much like in Saudi Arabia and Egypt, over time Islamist groups would utilise their role in society to challenge the regime, resulting in a clamp down on Islamist groups between 1989 and 1993. It also prompted constitutional changes to monitor and regulate Friday sermons, bringing 
mosques under the control of the Ministry of Awqaf Islamic Affairs and Holy Places. Constitutional placed religious institutions - including mosques - under supervision and provided training to those wishing to preach or offer Islamic guidance. ${ }^{74}$ Later reforms would also require written ministerial approval in order to give sermons and offer Islamic guidance, punished by a ban, jail sentence or fine.

As we have seen, Kuwait's political history of compromise created space for groups such as the Muslim Brotherhood to operate, yet unlike their counterparts in Egypt and Jordan, this action was driven by the harakat (movement) rather than the hizb (party). As one prominent Islamic figure noted, the Kuwaiti branch of the Muslim Brotherhood was formed in 1951 in response to burgeoning Western influence and amid the secular movements of Arab nationalism:

Our Islamic movement started in the early fifties, during the period in which Kuwait was under the fierce assault from Western concepts and values of secularism and nationalism, the most noticeable of which were the pan-Arab Nationalism, Ba'athism, and Socialism. Such an assault was meant to distract the Kuwaiti Muslims from their faith. That was the main reason for the establishment of political Islamic activities. ${ }^{75}$

Members of the newly formed ikhwan ran in local elections but as individuals rather than as members of the political party. ${ }^{76}$ Across Kuwaiti politics, the Constitutional Court occupies a central role, serving an intermediary role between different groups across the state and on some occasions ruling against the Al Sabah. ${ }^{77}$ Although often viewed with a sense of pride because of its spirit of dialogue and compromise, there are growing demands for reform of the social contract, which was initially due to be reformed in 1966 to reflect changing social and religious dynamics. ${ }^{78}$

In Lebanon, political parties have been mapped on to the sectarian construction of the state. ${ }^{79}$ After the civil war, the establishment of the consociational power-sharing system of government gave each sect a share in the running of the country as a means of providing each group with access to political space. While serving as a means of ensuring that all groups can express their views and grievances amid historical conditions of extreme poverty, marginalisation and violence, ${ }^{80}$ the system is flawed in the sense that it constitutionalises and enshrines sectarian difference in the political realm, creating a system that is easily deadlocked by veto powers. ${ }^{81}$

Although religious values have provided some actors with the ability to shape regional affairs, context remains central to such capacity. Some Shia Muslims in Lebanon, aware of the need to operate within a confessional system and fearing a return to the darker days of the civil war, express solidarity with their Christian kin by putting up Christmas decorations in a visible manifestation of the negotiation between the transnational - Twelver Shi'ism - and the national - Lebanese identity. ${ }^{82}$ For others, their faith shapes political behaviour in different ways. While faith may be abstract, we must not remove it from the context within which it operates, for it is the political, social and economic contexts that are given direction by religious beliefs and conversely, context shapes the capacity to act in a particular way. 
In Iraq, from the establishment of the state until 2003, sectarian difference was propagated as a mechanism of survival, seeking to limit the power of the Shi'a clerics and by (perceived) extension, Iran - and ensuring the survival of successive regimes. ${ }^{83}$ In response to historical discrimination, a number of Islamic parties - predominantly Shi'a - provided a political voice for those marginalised by the erstwhile regime. ${ }^{84}$ The most prominent of these parties, Al Da'awa Islamiyah, emerged in the late 1950s as a consequence of the impact of modernisation and marginalisation on communities. ${ }^{85} \mathrm{Al}$ Da'wa drew support from clerics across the south and was inspired by the theological ideas of the Iraqi Shi'a cleric Muhammad Baqir Al Sadr. Although most of its members were exiled to Iran, the party retained influence as a prominent opposition movement and played an important role in the post-2003 landscape. While based in Iran, Da'awa was supported by the creation of the Supreme Council of the Islamic Republic in Iraq, which was more vocal in its support of veleyat-e faqih. Despite possessing a sectarian dimension, Al Da'awa initially found support from a number of Sunni Muslims as a consequence of drawing on the writing of Sayyid Qutb. Some Shia clerics stressed unity, in spite of the conditions inside Iraq, perhaps most notably Al Sadr. ${ }^{86}$

In spite of such sentiments, when political contexts changed post 2003, relations between Sunni and Shia took on increasingly violent dimensions in their relations. While countless factors had shaped political life in the previous eighty years, the new political climate brought sectarian tensions to the fore, albeit shaped by a range of social, economic and tribal contingent factors.

Religion also found space in political structures in Bahrain. While also historically populated by secular, leftist and Arab nationalist parties, Shia opposition groups gained a great deal of support in Bahraini politics following the Iranian revolution. Relations between regime and opposition groups ebbed and flowed in the subsequent years, culminating in a 'decade of discontent' in the 1990s ${ }^{87}$ Amid socio-economic difference, religious symbolism played a prominent role in the construction of political opposition, drawing people together under a shared banner of Shi'a Islam. This symbolism played an important role in constructing unity and a Shi'a identity, within which religious figures such as Sheikh Isa Qassim serve as the spiritual leadership of parties like Al Wefaq. ${ }^{88}$ Religious denomination resulted in political, social and economic discrimination but grievances stemmed from such discrimination, where unemployment has disproportionately impacted upon Shi'a communities. ${ }^{89}$ Ultimately, the relationship between Shia parties and the regime is shaped by security calculations, which determines the nature of interactions.

The inability of groups across the region to capture and consolidate political power after the Iranian revolution led Olivier Roy to argue that political Islam 'failed'. ${ }^{90}$ Following the work of scholars such as Asef Bayat, in later works, Roy suggested that after its failure, Islam took on a more private dimension in what became known as post-Islamism. In this sense, Islamic commitment moves from the public realm into the private. The argument suggests that Muslims lost interest in transforming faith into a political ideology and social movement. Instead, moving away from state-led efforts to transform society, post-Islamism is a search for a form of Islamic 'good life' amid the fragmentation and transformation of traditional 
forms of religious authority and their relationships with state structures. To this end, 'contemporary re-Islamisation is a cluster of individual practices that are used as a means of finding jobs, money, respect and self-esteem, and bargaining with a marginalised state that has played on conservative re-Islamisation but been unable to control it.'. ${ }^{1}$

Amid the uncertainty of the modern world, faith provides a degree of certainty. ${ }^{92}$ In this case, the move to a more private Islam occurs with a new form of knowledge production and new application of Islam to the modern world. This also results in the emergence of a new type of preacher, able to speak to the urban youth while also demonstrating Quranic excellence in a single thought. ${ }^{93}$ Although suggesting a move towards the individualisation of religion, some such as Bayat demonstrate that in spite of such individualistic practice, Muslims also embody forms of the good life. ${ }^{94}$ Here we see the fusion of modernity with tradition and public with private in numerous discourses about human dignity and the good life. Such a move becomes increasingly important in the years leading up to the Arab Uprisings as previous failures of political aspirations created different forms of political expression and belonging, within both national and discursive collectives.

\section{Dar al Islam, dawla and umma}

Central to discussions about the relationship between Islam and sovereignty are questions about territory and jurisdiction, the ordering of life and the spatial limitations that emerge from such ordering. ${ }^{95}$ For some such as Majid Khadduri, Muslims are bound by the 'law' of their faith regardless of territory or place of residence. Yet such a position fails to accommodate the realities and contexts of individual Muslims and their communities, which shape their action and identity.

As Khadduri notes,

A distinction ... must be made between an authority which is directly derived from and exercised by God, and an authority which is derived from a divine code endowed by God but enforced by His viceregent (or by a secular ruler) which is equally binding upon the latter and the people. ${ }^{96}$

Tension over sources of authority is a prominent feature of debate over the role of religion in political organisation. The dawla and umma are fundamentally two discordant bedrocks for the contemporary state, revealing tensions between and within theological circles about the nature and trajectory of political organisation. ${ }^{97}$ Historical understandings are associated with the efforts of Jamal Al Din Al Afghani whose writings sought to mobilise Muslims across the world around the concept of Islamic unity. Afghani's work framed Islamic unity as a response to colonial oppression, where injustice provoked the need for collective response. Yet this was not a call for the rejection of the nation state, but rather a 'civilisational discourse' in response to colonialism..$^{98}$ 
The inability of Muslims across the world to identify with this imagined community' meant that Afghani's project ultimately failed in practice, but the legacy of his work continued. Rashid Rida's work in the aftermath of fall of the Ottoman Empire called for states to adopt the normative values of Islam - as found in the Sharia - which resulted in the establishment of groups such as the Muslim Brotherhood, working within the confines of territorial borders. ${ }^{99}$ In the following years, the concept of a broader pan-Islamic movement became associated with a more militant form of violent extremism who espoused membership of an umma as an imagined community akin to dar al Islam. ${ }^{100}$

The concepts of dar al Islam and dar al harb provide insight into the relationship between faith, law and territory. Dar al Islam is generally understood as 'the whole territory in which the law of Islam prevails', while dar al harb refers to land not encompassed by dar al Islam. ${ }^{101}$ Although Ibn Al Arabi depicted Islam as a single person, the concept of dar al Islam was binding to communities that, by their very nature had become territorial. ${ }^{102}$ For Parvin and Sommer, dar al Islam is 'a legal construct that has a territorial dimension: a territorial expression of the umma ... which itself has a political component. ${ }^{103}$

It is helpful at this point to return to the concept of the nomos to consider the roots of political organisation across the Islamic world. The concept provides insight into the relationship between law and territory, along with interpretations of 'how to live'. While early understandings of the nomos suggest an attachment to soil, consideration of preIslamic history across the Arabian Peninsula, reveals how the nomadic way of life left little attachment to land. The words of incitement used by Umar to aid the conquest of Iraq reveal a great deal in this regard: 'The Hijaz is your home only in as far as it is a pasturage. Those who dwell there have no power over it except in this respect. Where do newcomers who emigrated stand with regard to God's promise, "Roam the earth?" '104

Similar views are also found in the work of Khaldun, whose reflections of the nature of tribal life we have encountered previously. Speaking about the nomadic characteristics of the tribe, Khaldun notes that such groups

have no homelands they might use as a fertile (pasture), and no fixed place to which they might repair. All regions and places are the same to them. Therefore, they do not restrict themselves to possession of their own and neighboring regions. They do not stop at the borders of their horizon. They swarm across distant zones to achieve superiority over faraway nations. ${ }^{105}$

These remarks share similarities with Parvin and Sommer, who suggest that territoriality at this point was 'a function of time more than space', as territorial boundaries were defined through a tribe's movements. ${ }^{106}$ Such movements were later harnessed in an effort to facilitate the expansion of Islam, which became fixed with the development of communities. As the expansion of sovereignty began to wane, a more static, permanent sense of politics began to emerge, supplanting the personal, sociological character of Islamic sovereignty with an identity that was shaped by spatial and territorial factors. ${ }^{107}$ 
The emergence of divisions within the community was hardly surprising, in spite of widespread criticism from jurists at the time, who suggested that Islamic law 'recognises neither division in Moslem authority nor differentiation among Moslems on racial or cultural background. ${ }^{108}$ Amid these internal visions, the idea of the universal form of dar al Islam began to wane, ceasing to be able to shape the reality of its members. In spite of such concerns, the appearance of different groups was acknowledged in the Quran: 'We made you into nations and tribes so that you may know each other.'109

The emergence of divisions began to be categorised by cultural and political differences, while affinity with soil developed over time grounding communities in space. With the spread of Western ideas, first through the crusades and much later, the mandate system, territorial segregation became the primary form of political definition. ${ }^{110}$ Although some have suggested that Islam is incompatible with the concept of the territorially grounded nation state, ${ }^{111}$ Piscatori suggests that there is nothing about Islam that makes it incongruent with such ideas. ${ }^{112}$ While this position is certainly more accurate than others, there are tensions that emerge when we look at the political manifestations of Islam and its relationship with territory.

The German historian Reinhard Schulz argued that the umma served to reinforce the territorially grounded national state, ${ }^{113}$ as a range of different definitions of umma are given in the Quran. As a consequence, this plurality of meanings provides scope for actors to use it in particular contexts and for political reasons, creating a form of contingency. Of course, context is key in understanding the concept, as it is shaped by nationalism, states, movements and socio-economic forces.

As Fred Halliday suggests, the term umma

was available, in a range of meanings ... It is not surprising, therefore, that, on the one hand, the term, umma, should have become a common one in the political discourses of the Arab world in the twentieth century and that it should have a variety of distinct, equally licensed, meanings within both the discursive legacy of the substratum and the contemporary, world-historical, context of the Arab world. ${ }^{114}$

Halliday notes how the concept is contingent upon the complexities of contemporary political life. Supporting this thesis, Schulze argues that local and national interest far outweighed broader Islamic sentiments, particularly within moments of crisis, even in the burgeoning moments of the sovereign state. ${ }^{15}$

Discourses that mobilise the concept of the umma are based on such contingency; after all, ideas and discourse alone cannot transcend difference or indeed shape political activity. Instead, they rely on actors who are themselves shaped by context. ${ }^{116}$ As a consequence, we must consider the broader context that shapes contingency, as social, cultural, economic and historical factors shape group intentions, capabilities and the type of relationships that they have with society. Put another way, we must locate groups not only within ideological streams and socio-economic factors, but also geopolitical conditions. ${ }^{117}$ It is through this that we are able to understand the emergence of ideas and groups that reject the state in favour of broader transnational projects. ${ }^{118}$ 


\section{Geo-sectarian politics}

In addition to different spatial and temporal differences, faith is also characterised by distinct theological interpretations, resulting in the emergence of different sects. ${ }^{119}$ The roots of sectarian difference are initially political, stemming from dispute over who was to lead the caliphate after the death of Muhammad. This dispute reached its zenith on 10 October $680 \mathrm{AD}$ where Hussein, the grandson of the Prophet, and his followers were ambushed by a larger Ummayad force. In the ensuing battle at Karbala, Hussein and his young son were killed, along with all of his male companions. The Battle of Karbala is a central point within the history of Shia Islam, routinely marked in the festival of Ashura. Hussein had spent a great deal of his life challenging the perceived corruption of the Ummayad court, ultimately leading to his death at Karbala. The narrative of the battle creates ideas of guilt and martyrdom among Shi'a Muslims, as a consequence of ancestral failures to help Hussein and his followers. ${ }^{120}$

Historical developments at this time also document the emergence of the Kharijite movement - taken literally to mean those who rebel against religion - who rejected submission to human authority. After the Battle of Siffin ended in a truce, the Kharijites criticised Ali for ending the battle, rejecting his position as leader and the role of arbitrators in ending the war. The Kharijites took a literal reading of the Quran and the phrase la hukma ila lillah - there is no rule but God's - as a literal manifesto, rejecting all forms of human authority, even if this was God's representative on earth. ${ }^{121}$ The challenge of this idea also raised fundamental questions over authority, such as who determined the law and, in keeping with our discussion of sovereignty, who determines the exception?

While all Muslim states in the region refer to the Sharia within either constitutions or Basic Laws, the Islamic Republic of Iran explicitly uses it as the source of all of its laws. In the aftermath of revolution, the system of veleyat-e faqih enshrined the values of Twelver Shi'a thought within the fabric of the newly established Islamic Republic, which provided the state with much needed legitimacy. Moreover, the structure of veleyat-e faqih facilitated the regulation of both formal and informal space, thus harnessing the power of religion, something that the Shah had previously been unable to do.

While Khomeini's vision established the Islamic Republic, earlier in his life he had followed a more quietist trend within Shi'a thought, arguing that clerics should remain removed from politics. This view, as currently espoused by the likes of Grand Ayatollah Ali Sistani remains the predominant difference between the two great schools of Shi'a thought, in Qom and Najaf. In spite of such tensions, Khomeini articulated the compliance of veleyat-e faqih with Islam in a constitution that

advances the cultural, social, political, and economic institutions of Iranian society based on Islamic principles and norms, which represent an honest aspiration of the Islamic Ummah. This aspiration was exemplified by the nature of the great Islamic Revolution of Iran, and by the course of the Muslim people's struggle, from its beginning until victory, as reflected in the decisive and forceful calls raised by all segments of the population. ${ }^{122}$ 
Amid such comments, in its aftermath, the revolution was greeted with superficial optimism by some in Riyadh. Shortly after the establishment of the Islamic Republic, King Khalid proclaimed:

It gives me great pleasure that the new republic is based on Islamic principles which are a powerful bulwark for Islam and Muslim peoples who aspire to prosperity, dignity, and well-being. I pray the Almighty to guide you to the forefront of those who strive for the upholding of Islam and Muslims, and I wish the Iranian people progress, prosperity, and stability. ${ }^{123}$

Yet relations between the two quickly soured, as geopolitical and political concerns began to play an important role. It was here that sectarian difference also took on a security dimension, as the two sides expressed their intent and concerns. For Khomeini, Iran sought to 'export our experiences to the whole world and present the outcome of our struggles against tyrants to those who are struggling along the path of God.' ${ }^{124}$ Khomeini's comments were a source of great consternation for Sunni Arab states, not only through an apparent desire to spread the revolutionary goals of Shia Islam, but also to challenge the regional status quo. ${ }^{125}$

In response, a cycle of rhetoric emerged between the leaders of Saudi Arabia and Iran in an effort to demonstrate Islamic legitimacy. ${ }^{126}$ In pursuit of this, Khomeini sought to stress unity across the Muslim world:

There is no difference between Muslims who speak different languages, for instance the Arabs and the Persians. It is very probable that such problems have been created by those who do not wish the Muslim countries to be united ... They create the issues of nationalism, of pan-Iranianism, pan-Turkism, and such isms, which are contrary to Islamic doctrines. ${ }^{127}$

In spite of his efforts to foster unity, Khomeini was vociferously critical of the Al Saud who were seen as 'corrupt and unworthy to be the guardians of Mecca and Medina'128 and later referred to as 'traitors to the two holy shrines. ${ }^{129}$ In a damning indictment, Khomeini claimed that:

If we wanted to prove to the world that the Saudi Government, these vile and ungodly Saudis, are like daggers that have always pierced the heart of the Moslems from the back, we would not have been able to do it as well as has been demonstrated by these inept and spineless leaders of the Saudi Government. ${ }^{130}$

In response, King Fahd condemned the 'hypocrites and pretenders who are using Islam to undermine and destabilise other countries. ${ }^{131}$ Tensions erupted in violence on the 1987 hajj where an estimated 450 pilgrims died, of whom 275 were Iranian, ${ }^{132}$ which later resulted in the politicisation of hajj licenses and the Iranian boycott of the hajj. There was also an explicit attempt by Saudi leaders to frame the revolution as a Shi'a - Persian - event, seeking to reduce Tehran's appeal to Sunni communities. 
Although Khomeini spoke of providing support to the mustazefin (downtrodden), this was then to be placed within the context of long-standing Sunni-Shia tensions alongside suspicions about Persian expansionism. In the following years, the two states began to engage in ideological and political competition to increase their influence across the Middle East and wider Islamic community.

Perhaps the most visible manifestation of this was in the Organisation of Islamic Cooperation (OIC), the forum to resolve issues across the Islamic world. ${ }^{133}$ As Jeffrey Haynes notes, the OIC was plagued by contending visions of an 'appropriate' Islamic society, politicising belief and challenging the spirit of the organisation. ${ }^{134}$ Saudi dominance of the organisation is hardly surprising. The headquarters of the OIC are in Jedda, while the kingdom has donated large sums of money to the organisation and its various institutions. In return, Saudi Arabia possesses de facto veto power, while also seemingly uses the organisation as a platform to support its political agenda. In 2012, Saudi Arabia called for the suspension of Syria's membership of the OIC as a consequence of the Assad regime's violence against citizens. As tensions between the two major Gulf powers escalated, it was hardly surprising that the OIC became an arena for tensions to play out, resulting in the vocal condemnation of Iran for its continued support for terrorism' and for interfering in the domestic affairs of states across the Middle East. ${ }^{135}$

Beyond the OIC, both Saudi Arabia and Iran have capitalised on shared religious networks to exert influence across the Middle East, attempting to reduce the political influence of the other by funding religious groups. While Iraq offers an obvious example of such mobilisation, similar links can be drawn in Lebanon, Bahrain, Syria, Yemen, India, Pakistan, Indonesia and the Horn of Africa. It is widely acknowledged that Saudi Arabia has provided vast sums of money to clerics for spreading the Wahhabi message. ${ }^{136}$ One Shi'a cleric recounted a flight from Medinah that he shared with Imams returning home from receiving religious schooling in Saudi Arabia. In return for undertaking this training, the clerics received a monthly stipend along with support for their families. ${ }^{137}$ Yet in spite of this funding, their actions were shaped by local context. While Salafis have gained prominence in Lebanon, this is not the strict Wahhabist form of Salafism. A Lebanese journalist recalled visiting the home of a Salafi cleric, where he met the cleric's daughter who, much to his surprise, was 'wearing jeans and a T-shirt. ${ }^{138}$ Such a story demonstrates how transnational forces interact with local contexts to shape space in a particular way.

In times of uncertainty, shared religious values - transcending territorial borders provide the capacity to shape relations with groups beyond state borders. In postinvasion Iraq, US diplomatic cables released by WikiLeaks document the perceived role of Shi'a actors and, by extension, Iranian influence, including the funding of groups such as the Supreme Council for Islamic Revolution in Iraq (SCIRI) and Badr, in the region of $\$ 100$ million and $\$ 45$ million respectively. ${ }^{139}$ This campaign also involved engagement with Iraqi politics, where Iran was accused of pushing Maliki into a confrontation with the Sadrist movement to ensure the political dominance of its Iraqi allies and the spiritual dominance of the Persian marja'iyya. ${ }^{140}$

The implications of this for the ordering of space - and the territorial borders of such a project - are clear, with serious implications for sovereign power and space, as 
regional currents interact with the intricacies of life, across southern Iraq and also in Yemen where conflict took on an increasingly sectarian nature amid the conflation of domestic politics into geopolitical currents shaping the Middle East. ${ }^{141}$

\section{A zone of indistinction}

As we have seen, religion exists simultaneously as a zone of possibility and restriction. Within this zone, believers find guidance on how to live, regimes find the means to legitimise their rule, and dissidents find the tools through which to challenge political order. Interpretation of text and tradition thus serves as a source of possibility, shaped by the interaction of context-specific contingency. Ultimately, what we have seen across the Middle East is that religion has become the arena through which states and their opponents can play out their political struggles amid competing visions of how to live. With its role in public life, religion becomes the means through which dissent in a range of different guises - can emerge. Even when religious space is restricted, narratives and norms can be used as a means to challenge the status quo and to shape life both formally and informally.

Moreover, Islam serves as a means through which ruling elites can increase legitimacy by stressing conformity with Islamic norms and practices. This then opens up scope for criticism as regimes may not be seen as Islamic enough, leading to challenges from opposition movements on religious grounds. Thus, religion exists as a double-edged sword, simultaneously serving to legitimise and delegitimise, depending upon the particular contexts in operation. If this is so, there is more to religion than faith and a discussion about the organisation of society. Instead, there appears to be a greater existential dimension to the role played by religion within political community: as a zone of indistinction, contingent upon interpretation that shapes the spatial ordering of life.

We can see how Islam becomes the vehicle through which opposition emerges, requiring regulation from regimes in an attempt to maintain control. Such regulation ranges from fatwas justifying behaviour, to the banning of groups from particular backgrounds. Historically, political opposition has also been marginalised by regimes that have cultivated sectarian master narratives, wherein the grievances of political agents have been subsumed by broader debate around legitimacy of belief. Yet within conditions of regulation and control, religion also serves as an ideological framework to challenge the status quo and to mobilise networks against state structures, opening tension between ordnung and ortung. Inherent within Islam are structures that help spread ideas and mobilise people, which has long been a source of concern, leading to the regulation and monitoring of Friday prayers. Here, the mosque becomes a battleground of ideas to shape the attitudes of the public.

Such issues are not unique to Islam; instead, they can be found whenever there is certainty of belief. ${ }^{142}$ For example, Israel is often referred to as a 'Jewish and democratic' state yet as number of Israeli scholars have acknowledged, this political system is better suited by the concept of 'ethnocracy.' ${ }^{143}$ As Oren Yiftachel argues, ethnocratic regimes 'promote the expansion of the dominant group in contested territory and its 
domination of power structures while maintaining a democratic façade'. In the Israeli case, this form of ethnocracy reflects the broader Zionist strategy of 'Judaizing the homeland'144 and the physical transformation of the land. ${ }^{145}$

In the Israeli case, the expansion of the dominant group is at the cost of Palestinians in the West Bank and Gaza, along with other ethnic groups in Israel proper. Essentially, Yiftachel suggests that the process of Judaising the 'Land of Israel' creates a set of power relations that shape interactions between Israelis and Palestinians, between Ashkenazi and Mizrahi Jews, Orthodox and secular Jews and many other groups. It is a holistic approach that facilitates existential transformation of life across Israel and Palestine in the quest to Judaise territory, as a form of 'creeping apartheid. ${ }^{146}$ Moreover, it is an attempt to order space, defining spatial borders in the process, albeit with competing visions of how to live. Here, nomos is itself a zone of indistinction, serving to legitimise a range of different positions.

Although there is little doubting the impact of Judaism upon life across Israel, symbolically, politically and socially, an important impact concerns settlement policies. Religious views of the so-called 'Land of Israel' vary depending upon interpretation and the fusion of Torah and political factors on the ground. Beyond Israel proper, ideological views found in the religious Zionism trend - itself not a homogenous bloc - have shaped political action across the West Bank. Such action has taken place by both state and non-state actors, using land transformation as a mechanism for political expansion. ${ }^{147}$ Settler movements have long been used as a means to define the nation and its citizens, but across the West Bank this has an impact on both Israel and Palestine. As we shall see in the next chapter, the transformation of urban landscapes plays a prominent role in the regulation of political life but before reaching this point we must consider the religious views that have shaped settlement behaviour beyond the formal practices of the state.

Although initially resistant to the civilian presence in the West Bank, which had previously been designated as a military zone to abide by international law, resettlement efforts driven by civilians - led by the group Gush Emunim - were given approval by Prime Minister Levi Eshkol who famously pronounced, 'Well kids, if you want to - ascend'. Demonstrating the importance of territory, an alternative transliteration of this quote reads, 'Children, you may return home. ${ }^{148}$ In the aftermath of this proclamation, the ascent into the hills of the West Bank was undertaken by some 20 trucks and cars carrying around 100 settlers along with Rabbi Zvi Yehuda Kook, the settlers' spiritual guide. ${ }^{149}$

Following this effort, the settlers published a pamphlet detailing the importance of civilian settlement. In it, the pamphlet proclaimed that the group 'set out today to found a city in the heart of Eretz-Israel near Nablus.' ${ }^{150}$ The settlers and military apparatus of the state agreed upon the terms of the civilian presence in the West Bank, building settlement housing and services. The Secretary of Gush Emuni, Zvi Slonim, later reported that

in 'basement' conditions yet 'penthouse' morale ... the settlement gradually constructed itself as a separate entity ... Supporters who came here saw the 
making of a new form of pioneer life ... [and] were sparked with the seed that fruited with more and more Elon Moreh [settlements] in Judea and Samaria. ${ }^{151}$

Such efforts sought to transform the West Bank from 'enemy territory' to Jewish homeland.

Later plans outlined far more ambitious projects seeking to transform life in the West Bank and Gaza. Negotiating a difficult relationship with political elites in Israel, large aspects of the settlement project were consumed by state apparatus wherein the transformative aspect was used for political and security purposes. The success of such transformative processes is revealed when we consider that Avigdor Lieberman, the Israeli Defence Minister (who made aliyah from the former Soviet Union) is a West Bank settler, embodying the breach of international law and conventions while serving as a high-ranking official in the Israeli government. ${ }^{152}$

Political disengagement from the West Bank and Gaza proved incendiary, moving away from a theological imaginary and a political vision. This goes some way to explaining the violence that erupted amid the disengagement from Gaza and the destruction of 'illegal' settlements. ${ }^{153}$ Such illegal settlements push the sovereignty of the Israeli state beyond the territorial borders in search of a broader vision of Eretz Israel. A secondary point of tension stemming from the relationship between Judaism and the state concerns the role of the ultra-Orthodox in the military. Competing views on the source of sovereignty emerge when considering military action in the West Bank and Gaza. Disengagement policies were deeply contested by a range of religious sources who rejected the political decision to withdraw, leading to widespread protests.

Although previously exempt from the military service that is compulsory for all other Israelis, a long-running legal battle was ended when the Supreme Court declared the exemption to be 'discriminatory' and 'unconstitutional. ${ }^{154}$ With concerns that the IDF was becoming more religious, fears about disobeying military orders increased amid calls for disobedience from individuals such as Rabbi Avraham Shapira, a former Chief Rabbi of Israel, and leader of Merkaz HaRav Kook. ${ }^{155}$ Following acts of disobedience, Ha'aretz, a leading Israeli newspaper, published an opinion piece entitled 'Drafting Ultra-Orthodox Jews into the Israeli Army Is Dangerous. ${ }^{156}$ When faced with such decisions, soldiers face a test of their loyalty: to their state or their Rabbi. As the political situation becomes increasingly complex, such tensions will strike at the very heart of the Israeli state amid efforts to exert sovereign power.

\section{Conclusions}

When placed in political and economic context, religion is a means through which individuals can be included/excluded from state structures, while also serving to shape political activity through intellectual curiosity, ethical values and normative behaviour. Amid the uncertainty of modernity and a fragmenting regional system, the certainty provided by faith has proved attractive to many. Within the Middle East, the existence 
of groups who run welfare programmes and offer moral certainty prove attractive and those who are able to offer protection amid uncertainty can develop widespread support.

Although often overlooked by scholars of politics and other disciplines, we should remember to acknowledge that faith is a means for action in and of itself. While scholars are quick to consider how faith is populated with political meaning, we should not disregard belief. That being said, we can also explore the political dimensions that are taken alongside belief as a consequence of tensions between different ideas about the role of religion within society that are ultimately grounded in contingency. Discussion about membership of communities of faith leads to division, contingent on a range of factors. Much like the nomos, unity is a fleeting instance that fragments into countless different visions with their own regulatory capacity. As a consequence, we should not seek to reify religion as a homogenous force; rather, we must remember that it is shaped by particular experiences of economic, social, ideological, historical and geopolitical interactions.

While simultaneously creating a nomos by seeking to regulate behaviour, it is shaped by particular contexts. Historically, debate about the relationship between religion and politics shaped society, whereas at present, the debate serves as a means of ensuring control and regulation over society. Within this position, the range of normative, structural, cultural and multifarious positions within religion broadly serves as a mechanism through which governance - and biopolitical control - can be exerted. Religion is then central to political struggles but also broader efforts to regulate life and define spatial borders.

Within political projects are countless interpretations and narratives that reflect regime, opposition and populist views that quickly spread within and between states. With the spread of TV, radio, print media and the Internet, individuals are also able to access the views of figures in neighbouring states, speaking to local populations, but also across a region as a whole. Complicating matters is the fact that each position is then interpreted by individuals who are shaped by history, culture, society, economic and political factors, leading to a plurality of views before ascertaining the nature of one's faith. Fundamentally, this discussion relates to the regulation of life within particular territories, shaped and defined by both time and space. But it also provides scope for challenges to the manner in which life is regulated, a means through which legitimate challenge to the status quo can emerge. As such, Islam simultaneously serves as a source of authority and of opposition, a zone of indistinction that is necessarily and simultaneously - a zone of possibility and repression.

Within these conditions, regimes often constructed and referred to sectarian master narratives in an attempt to ensure their survival, deepening divisions within already fractious societies. Sectarian difference served as a mechanism of control, with explicit support for particular sects over others who were often then politicised and securitised, showing the power of norms to shape formal structures. The construction of narratives of belonging can transcend state borders to easily result in theological debate possessing both political and geopolitical ramifications. This also 
provides the mechanisms through which foreign policy goals can be reached, when theological narratives cross borders and become shaped by the contingency of local context.

\section{Notes}

1 Shadi Hamid, Islamic Exceptionalism: How the Struggle Over Islam Is Reshaping the World (New York: St Martin's Press. 2016).

2 Nazih Ayubi, Political Islam: Religion and Politics in the Arab World (London: Routledge, 1991).

3 Ali Abd Al Raziq, Al-Islam wa Usul al-Hukm (Cairo: n.p., 1925).

4 A. Sanhoury, Le Califat: Son Evolution vers une Societe des Nations Orientale [The Caliphate: Its Evolution Towards a Society of Oriental Nations] (Paris: Libraire Orientaliste Paul Geuthner, 1926), cited in Majjid Khadduri, 'Islam and the Modern Law of Nations', American Journal of International Law, 50:2 (1956) 358-72.

5 Majjid Khadduri, War and Peace in the Law of Islam (Baltimore, MD: Johns Hopkins Press, 1955), pp. 3-18.

6 Quran 5:40.

7 Andrew F. March, 'Genealogies of Sovereignty in Islamic Political Theology'.

8 See Charles Kurzman, The Unthinkable Revolution in Iran (Cambridge, MA: Harvard University Press, 2004); Nikki Keddie, Modern Iran: Roots and Results of Revolution (New Haven, CT: Yale University Press); Baqer Moin, Khomeini: Life of the Ayatollah (New York: Thomas Dunne Books, 2000). See also Robert Fisk, The Great War for Civilization: The Conquest of the Middle East (London: Harper Perennial, 2006).

9 See Simon Mabon, 'The Circle of Bare Life: Hizballah, Muqawamah and Rejecting "Being Thus", Politics, Religion and Ideology, 18:1 (2017), 1-22; Rola El-Husseini, 'Hezbollah and the Axis of Refusal: Hamas, Iran and Syria', Third World Quarterly, 31:5 (2010), 803-15; Edith Szanto, 'Beyond the Karbala Paradigm: Rethinking Revolution and Redemption in Twelver Shia Mourning Rituals', Journal of Shia Islamic Studies, 6:1 (2013), 75-91.

10 A vast literature on Hizballah exists, including Augustus Richard Norton, Hezbollah: A Short History (Princeton, NJ: Princeton University Press, 2007); Nicolas Blanford, Warriors of God: Inside Hezbollah's Thirty-Year Struggle Against Israel (New York: Random House, 2011); Worrall et al., Hezbollah; Judith Palmer Harik, Hezbollah: The Changing Face of Terrorism (London: I. B. Tauris, 2005); Adham Saouli, Hezbollah: Socialisation and Its Tragic Ironies (Edinburgh: Edinburgh University Press, 2018).

11 See Roy Wallis, Sectarianism: Analyses of Religious and Non-Religious Sects (London: Peter Owen, 1975); Lawrence Potter, Sectarian Politics in the Persian Gulf (London: C. Hurst \& Co., 2013); Jacqueline Ismael and Tareq Ismael, 'The Sectarian State in Iraq and the New Political Class', International Journal of Contemporary Iraq $i$ Studies, 4:3 (2010); Simon Mabon and Lucia Ardovini (eds), Sectarianism in the Middle East (Oxford: Routledge, 2017), among many others.

12 Haddad, "Sectarianism" and Its Discontents'.

13 For the primordialist, identities exist in a fixed manner, reinforced through biological factors and through association with territory. Culture and tradition reinforce such identities. In contrast, the constructivist holds that identities are imagined and 
fabricated around a particular theme, suggesting that the political community is an imagined concept.

14 See the work of Joseph Nevo, 'Religion and National Identity in Saudi Arabia', Middle Eastern Studies, 34:3 (1998), 34-53.

15 Olivier Roy, The Failure of Political Islam (London: I. B. Tauris, 1994).

16 Asef Bayat, Islam and Democracy: What Is the Real Question? ISIM Paper 8 (Amsterdam: Amsterdam University Press, 2007), p. 10.

17 Shahab Ahmed, What Is Islam? The Importance of Being Islamic (Princeton, NJ: Princeton University Press, 2016), p. 114.

18 Ibid., p. 147.

19 Ibid., p. 141.

20 Ibid., p. 275.

21 Manoucher Parvin and Maurie Sommer, 'Dar al-Islam: The Evolution of Muslim Territoriality and Its implications for Conflict Resolution in the Middle East', International Journal of Middle East Studies, 11(1980), 3.

22 Agamben talks about playing with the law; the idea of playing with religion is mine.

23 James Piscatori, 'Order, Justice, and Global Islam', in R. Foot, J. Gaddis and A. Hurrell (eds), Order and Justice in International Relations (Oxford: Oxford University Press, 2003), pp. 262-92, at p. 267.

24 Joseph Schacht, An Introduction to Islamic Law (Oxford: Clarendon Press, 1964), p. 200.

25 Dale F. Eickleman and James Piscatori, Muslim Politics (Princeton, NJ: Princeton University Press, 1996), p. 4.

26 Duncan B. Macdonald, Development of Muslim Theology, Jurisprudence and Constitutional Theory (New York: Russell \& Russell, [1903] 1965), p. 66.

27 Schacht, An Introduction to Islamic Law, p. 200.

28 Hossein Esmaeili, 'The Nature and Development of Law in Islam and the Rule of Law Challenge in the Middle East and the Muslim World, Connecticut Journal of International Law, 26:329 (2010), 344.

29 Sayyid Abul A'la Maududi, The Islamic Law and Constitution (Khurshid Amhad ed. and trans.), 7th ed. (Lahore, Pakistan: Islamic Publications, [1955] 1980).

30 Clark B. Lombardi, 'Designing Islamic Constitutions: Past Trends and Options for a Democratic Future', International Journal of Constitutional Law, 11:3 (2013), 619.

31 Sami Zubaida, 'Contemporary Trends in Muslim Legal Thought and Ideology', in Robert W. Hefner (ed.), The New Cambridge History of Islam: Muslims and Modernity: Culture and Society Since 1800 (Cambridge, UK: Cambridge University Press, 2010), p. 270. See also Robert W. Heffner, 'Introduction', in Robert. W. Heffner (ed.), Shar'ia Politics: Islamic Law and Society in the Modern World (Bloomington: Indiana University Press, 2011).

32 Nathan J. Brown, 'Shari'a and State in the Modern Muslim Middle East', International Journal of Middle Eastern Studies, 29 (1997), 359-76.

33 Ajami, The Arab Predicament; and Ayubi, Overstating the Arab State.

34 For a greater discussion of this see Parvin and Sommer, 'Dar al-Islam'.

35 Khadduri, War and Peace in the Law of Islam, p. 46.

36 Quran 48:28.

37 Quran 6:153.

38 See Julius Wellhausen, The Religio-Political Factions in Early Islam (Oxford: NorthHolland Publishing, 1975). 
39 Andrew F. March, 'Genealogies of Sovereignty in Islamic Political Theology', Social Research (Special Issue on Political Theology), 80:2 (Spring 2013), 293-320.

40 Ibid.

41 Seyyed Hossein Nasr, The Heart of Islam: Enduring Values for Humanity (New York: HarperCollins, 2002), pp. 117-18.

42 Alī 'Abd Al Rāziq, al-Islām wa uṣūl al-ḥukm: baḥth fill-khiläfa wa'l-ḥukūma fill-Islām (Cairo: Mațba at Miṣr, 1925). English translation: Ali Abdel Razek, Islam and the Foundations of Political Power (Maryam Loutfi trans. and Abdou Filali-Ansary, ed.) (Edinburgh: Edinburgh University Press, 2012).

43 Muhammad Rashīd Rị̣ā, Al- Khilāfa aw al-Imāma al- 'Uẓma (Cairo: al-Zahrā' li'li'lām al-'arabī, [1922] 1988).

44 Paul Brykczynski, 'Radical Islam and the Nation: The Relationship Between Religion and Nationalism in the Political Thought of Hassan al-Banna and Sayyid Qutb, History of Intellectual Culture, 5:1 (2005), 7.

45 Hassan Al Banna, 'Towards the Light', in Charles Wendell (ed.), The Five Tracts of Hassan al-Banna (Berkeley: University of California Press, 1975), p. 107.

46 Hassan Al Banna, To What Do We Invite Humanity? (Cairo: n.p., 1934). This was also published as a pamphlet in 1936, available at http://thequranblog.files.wordpress.com/ 2008/06/_2_to-what-do-we-invite-humanity.pdf (accessed 10.10.12).

47 Hamid, Islamic Exceptionalism. Countless Islamist groups exist, shaped by context and interpretation. Some locate themselves within political structures while others call for revolution.

48 Sayyid Qutb, Ma 'ālim fi'l-Ṭarīq [Milestones] (Cairo: Dār al-Shurūq, 1964), p. 8.

49 For discussion of the transnational, see Fawaz A. Gerges, The Far Enemy: Why Jihad Went Global (Cambridge, UK: Cambridge University Press, 2005); and Olivier Roy, Globalized Islam-Fundamentalism, Deterritorialization and the Search for a New Ummah (London: Hurst, 2004), among others. For a discussion of the national, see Gilles Kepel, Jihad: The Trail of Political Islam (London: I. B. Tauris, 2002); and Roy, The Failure of Political Islam, among others.

50 Michelle Burgis, 'Faith in the State? Traditions of Territoriality and the Emergence of Modern Arab Statehood, Journal of the History of International Law, 11 (2009), 53.

51 Ayatollah Ruhallah Khomeini, Hukumat-iIslami (Najaf: n.p., 1971), pp. 62-3.

52 Mounia Bennani-Chraibi, Soumis et rebelles: les jeunes au Maroc. (Paris: CNRS Editions, 1994), p. 243.

53 See Simon Mabon, 'Sovereignty, Bare Life and the Arab Uprisings', Third World Quarterly, 38:8 (2017) 1782-99.

54 Gerges, Makings the Arab World; and Ayubi, Overstating the Arab State, p. 1.

55 Nevo, 'Religion and National Identity in Saudi Arabia'.

56 For a biography of Faisal see Joseph A. Kechichian, Faysal: Saudi Arabia's King For All Seasons (Gainesville, FL: University Press of Florida, 2008). For Sadat, see his autobiography, In Search of Identity (New York: Harper Collins, 1978).

57 Kepel, Jihad, p. 61. For a detailed discussion of the establishment of the Islamic University of Medina, see Farquar, Circuits of Faith.

58 Hamid Algar, Wahhabism: Acritical Essay (New York: Islamic Publications International, 2002); Madawi Al Rasheed, A History of Saudi Arabia (Cambridge, UK: Cambridge University Press, 2002), p. 164.

59 David D. Commins, The Wahhabi Mission and Saudi Arabia (London: I.

B. Tauris, 2006). 
60 Said K. Aburish, The Rise, Corruption and Coming Fall of The House of Saud (London: Bloomsbury, 1994).

61 Nevo, 'Religion and National Identity in Saudi Arabia', p. 35.

62 Saudi Constitution, available at www.constituteproject.org/constitution/Saudi_Arabia_ 2013.pdf?lang=en (accessed 10.02.08).

63 Aharon Layish, 'Ulama and Politics in Saudi Arabia', in Metin Heper and Raphael Israeli (eds), Islam and Politics in the Modern Middle East (London: Croom Helm, 1984), p. 56.

64 Rif'at Sayid Ahmad (ed.), Ras'il Juhayman al-'Utaybi: Qa'id al-Muqtahiminlil-Masjid al-Haram bi-Makka (Cairo: n.p., 1988).

65 Amin Al Sa'ati, Al-Shura fi al-Mamlaka al-'Arabiya al-Sa'udiya (Cairo, 1992), pp. 109-15.

66 Joseph A. Kechichian, 'The Role of the Ulama in the Politics of an Islamic State: The Case of Saudi Arabia', International Journal of Middle Eastern Studies, 18, 53-71.

67 Fouad Ibrahim, The Shi' is of Saudi Arabia (London: Saqi Books, 2006), p. 26.

68 For a detailed discussion of this see Toby Matthiesen, The Other Saudis: Shiism, Dissent and Sectarianism (Cambridge, UK: Cambridge University Press, 2014).

69 Meir Hatina, 'Historical Legacy and the Challenge of Modernity in the Middle East: the Case of al-Azhar in Egypt', The Muslim World, 93 (2003), 51-68.

70 Daniel Crecelius, 'Non Ideological Responses of the Egyptian Ulama to Modernazation', in Nikki R. Keddie (ed.), Scholars, Saints and Sufis. Muslim Religious Institutions in the Middle East since 1500 (Berkeley: University of California Press, 1972), p. 208.

71 See Olivier Roy, 'Les Nouveaux Intellectuals islamistes: Essai d’approach philosophique', in Giles Kepel and Yann Richard (eds), Intellectuals et Militants de l'Islam Contemporain (Paris: Seuil, 1991).

72 Malika Zeghal, 'Religion and Politics in Egypt: The Ulema of Al-Azhar, Radical Islam and the State (1952-94)', International Journal of Middle East Studies 31(1999), 371-99.

73 Steven Barraclough, 'Al-Azhar: Between the Government and the Islamists', Middle East Journal, 52:2 (1998), 236-49.

74 See http://lob.gov.jo/ui/laws (accessed 15.05.2010).

75 Abdullah al'Ali al-Mutawa, quoted in Sami Awadh, 'Islamic Political Groups in Kuwait: Roots and Influence' (PhD dissertation, University of Exeter, 1988), p. 179.

76 S. N. Al Khalidi, Al-Ahzab Al-Islamia fil-Kuwait: Al-Shia, Al-Ikhwan, Al-Salaf [Islamic Parties in Kuwait: The Shi'a, The Brotherhood, The Salafis] (Kuwait: Dar Al-Naba' LilNashar wa-I-Tawzi' (1999), p. 175.

77 Interview with Kuwaiti academic, 2018.

78 Ibid.

79 Knudsen and Kerr, Lebanon.

80 Augustus R. Norton, Amal and the Shia: Struggle for the Soul of Lebanon (Austin: University of Texas Press, 1987).

81 Knudsen and Kerr, Lebanon.

82 Interview with Lebanese journalist, 2017.

83 Simon Mabon and Stephen Royle, The Origins of ISIS: The Collapse of Nations and Revolution in the Middle East (London: I. B. Tauris, 2017).

84 Hanna Batatu, 'Iraq's Underground Shi'I Movements' (MERIP, 1981), available at www.merip.org/mer/mer102/iraqs-underground-shii-movements (accessed 13.12.15). 
85 Soren Schmidt, 'The Role of Religion in Politics. The Case of Shia-Islamism in Iraq', Nordic Journal of Religion and Society, 22:2 (2009), 129.

86 Amatzia Baram, 'The Radical Shi' ite Opposition Movements in Iraq', in Emmanuel Sivan and Menachem Friedman (eds), Religious Radicalism and Politics in the Middle East (Albany: State University of New York Press, 1990), pp. 108-9.

87 Frederic Wehrey, 'Bahrain's Decade of Discontent', Journal of Democracy, 24:3 (2013), $116-26$.

88 Steven Wright, Fixing the Kingdom: Political Evolution and Socio-Economic Challenges in Bahrain (Doha: Center for International and Regional Studies, Georgetown University, Qatar, 2008).

89 Luayy Bahri, 'The Socioeconomic Foundations of the Shiite Opposition in Bahrain', Mediterranean Quarterly, 11:3 (2000), 129-43.

90 Roy, The Failure of Political Islam.

91 Oliver Roy, Globalized Islam: The Search for a New Umma (New York: Columbia University Press, 2004), p. 99.

92 Simon Mabon, 'ISIS: Sectarianism, Geopolitics and Strong/Weak Horses' (eInternational Relations, 10.04.15), available at www.e-ir.info/2015/04/10/isissectarianism-geopolitics-and-strongweak-horses (accessed 10.04.15).

93 Peter Mandaville, 'Transnational Muslim Solidarities and Everyday Life', Nations and Nationalism, 17:1 (2011), 7-24.

94 Asaf Bayat, 'Islamism and Social Movement Theory', Third World Quarterly, 26:6 (2005), 904.

95 See Matthew Derrick, 'Containing the Umma? Islam and the Territorial Question', Interdisciplinary Journal of Research on Religion, 9 (2013), 1-30.

96 Khadduri, War and Peace in the Law of Islam, p. 14.

97 See Tamim Al Barghouti, The Umma and the Dawla: The Nation State and the Arab Middle East (London: Pluto Press, 2008).

98 Mandaville, 'Transnational Muslim Solidarities and Everyday Life', p. 9.

99 Ibid., p. 10.

100 See Thomas Hegghammer, Jihad in Saudi Arabia: Violence and Pan Islamism Since 1979 (Cambridge, UK: Cambridge University Press, 2010).

101 Encyclopedia of Islam, 2nd ed. (London: Luzac \& Co., 1960), s.v. dar al-Islam, p. 127.

102 See G. E. von Grunebaum, 'Islam: Its Inherent Power of Expansion and Adaptation', in G. E. von Grunebaum, Modern Islam: The Search for Cultural Identity

(New York: Vintage Books, 1964), p. 1. See also Khadduri, War and Peace in the Law of Islam, p. 43.

103 Parvin and Sommer, 'Dar al-Islam, pp. 4-5.

104 Ibid., p. 7. In the Quran this sentiment is shared at: 6:11, 27:69, 29:20, 30:42.

105 Khaldun, The Muqaddimah, p. 295.

106 Parvin and Sommer, 'Dar al-Islam', p. 7.

107 Ibid., p. 11.

108 Khadduri, War and Peace in the Law of Islam, p. 157.

109 Quran 49:13.

110 Majid Khadduri (trans.), The Islamic Law of Nations: Shaybani's Syiar (Baltimore, MD: Johns Hopkins Press, 1966), p. 65.

111 Authors such as Huntington and Lewis are thus guilty of denying local agency.

112 James Piscatori, Islam in a World of Nation-States (Cambridge, UK: Cambridge University Press, 1986), p. vii. 
113 Reinhard Schulze, A Modern History of the Islamic World (London: I. B. Tauris, 2000), p. 303.

114 Fred Halliday, 'The Politics of the Umma: States and Community in Islamic Movements', Mediterranean Politics, 7:3 (2002), 27-8.

115 Schulze, A Modern History of the Islamic World, p. 41.

116 Halliday, 'The Politics of the Umma'.

117 Eickleman and Piscatori, Muslim Politics.

118 Interview with Lebanese journalist, 2017.

119 Peter Berger, 'The Sociological Study of Sectarianism', Social Research, 51:1/2 (1984), 367-85.

120 Mabon, 'The Circle of Bare Life'.

121 March, 'Genealogies of Sovereignty in Islamic Political Theology'.

122 Iranian Constitution, available at www.constituteproject.org/constitution/Iran_1989. pdf?lang=en (accessed 10.02.08).

123 Lawrence Rubin, Islam in the Balance: Ideational Threats in Arab Politics (Palo Alto, CA: Stanford Security Studies, 2014), p. 52.

124 Ibid., p. 7.

125 Chubin and Tripp, Iran-Saudi Arabia Relations and Regional Order.

126 Mabon, Saudi Arabia and Iran.

127 Amirahmadi Hooshang, and Nader Entessar (eds), Iran and the Arab World (Basingstoke, UK: Palgrave Macmillan, 1993), p. 3.

128 Con Coughlin, Khomeini's Ghost (London: Macmillan, 2009), p. 274.

129 'Excerpts from Khomeini's Speeches' (New York Times, 04.08.87), available at www.nytimes.com/1987/08/04/world/excerpts-from- khomeini-speeches. $\mathrm{html}$ ? pagewanted $=$ all\&src $=\mathrm{pm}($ accessed 11.02.08).

130 Ibid.

131 See Jacob Goldberg, 'The Saudi Arabian Kingdom', in Itovar Rabinovich and Haim Shaked (eds), Middle East Contemporary Survey Volume XI: 1987 (Boulder, CO: Westview Press, 1987), p. 589.

132 Widespread allegations exist that such events were orchestrated by the Iranian Revolutionary Guards. See Goldberg, 'The Saudi Arabian Kingdom', p. 590.

133 Turan Kayaoglu, The Organization of Islamic Cooperation: Politics, Problems, and Potential (New York: Routledge, 2015).

134 Jeffrey Haynes, Religion and Development: Conflict or Cooperation (Basingstoke, UK: Palgrave Macmillan, 2007), p. 95.

135 Yesim Dikmen and Melih Aslan, 'Muslim Nations Accuse Iran of Supporting Terrorism: Summit Communique' (Reuters, 15.04.2016), available at www.reuters. com/article/us-turkey-summit/muslim-nations-accuse-iran-of-supportingterrorism-summit-communique-idUSKCNOXC1LQ (accessed 15.04.06). See also Bassel F. Salloukh, 'The Arab Uprisings and the Geopolitics of the Middle East', International Spectator, 48:2 (2013), 32-46.

136 Hussein Kalout, 'The Struggle for Islamic Supremacy', Global Discourse, 7:2-3 (2017), 357-70.

137 Interview with Iraqi Shi'a cleric, 2015.

138 Interview with Lebanese journalist, 2017.

139 'Building a House on Shifting Sands: Iran's Influence in Iraq's Center-South, (WikiLeaks, 20.07.05), available at www.wikileaks.org/plusd/cables/ 05BAGHDAD3015_a.html (accessed 12.12.05). 
140 'Sadrist Confidante Warns of Bad Pressure Building Within Sadrist Movement' (WikiLeaks, 09.04.08), available at https://wikileaks.org/plusd/cables/ 08BAGHDAD1105_a.html (accessed 12.12.15).

141 See Stacey Philbrick Yadav, 'Sectarianization, Islamist Republicanism, and International Misrecognition in Yemen', in Hashemi and Postel (eds), Sectarianization, p. 188.

142 Matthew T. Johnson and Simon Mabon, 'Fundamentalism: Explaining the "NonLiberal" Approaches to "Unreasonable" Doctrines', Australian Journal of Political Science, 53:2 (2018), 1-16.

143 See the work of Oren Yiftachel, in particular Ethnocracy: Land and Identity Politics in Israel/Palestine (Philadelphia: University of Pennsylvania Press, 2006).

144 Ibid, p. 3.

145 A prerequisite for Carl Schmitt.

146 Yiftachel, Ethnocracy, p. 7.

147 In a manner reminiscent of Schmitt's idea of the nomos, yet as laws and norms took form, we see mechanisms for regulating life emerge.

148 See Ariyeh Ruttenburg and Sandy Amichai, The Etzion Bloc in the Hills of Judea (Kfar Etzion: Kfar Etzion Field School, 1997).

149 Yael Allweil, 'West Bank Settlement and the Transformation of the Zionist Housing Ethos from Shelter to Act of Violence', Footprint: Spaces of Conflict, 19 (2016), 13-36.

150 Ibid.

151 Zvika Slonim, 'Daf Lamityashev' (Gush Emunim, 1980), pp. 1-2, cited in Allweil, 'West Bank Settlement', pp. 13-36.

152 Yiftachel, Ethnocracy, p. 5.

153 All settlements are deemed illegal by international law but in this case, I refer to those deemed illegal by Israeli law, the unofficial processes that challenge the sovereignty of the state and provoked widespread opposition.

154 'Israel's Military Exemption for Ultra-Orthodox is Ruled Unconstitutional' (New York Times, 09.12.17), available at www.nytimes.com/2017/09/12/world/middleeast/israelultra-orthodox-military.html (accessed 15.09.17).

155 Stuart A. Cohen, 'Tensions Between Military Service and Jewish Orthodoxy in Israel: Imagined and Real', Israel Studies, 12:1 (2007), 103-26.

156 Carolina Landsmann, 'Drafting Ultra-Orthodox Jews into the Israeli Army is Dangerous' (Ha'aretz, 15.09.17), available at www.haaretz.com/opinion/.premiumdrafting-ultra-orthodox-jews-into-the-israeli-army-is-dangerous-1.5451098 (accessed 15.09.17). 